\title{
Frank Robert Coffin
}

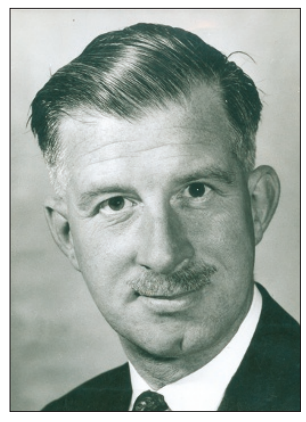

in the 1950s and 60s.
Frank Robert Coffin was born in London on 21 September 1915, and died suddenly on 13 January 2004 at the age of 88 years. His career as an oral surgeon spanned the war years and was centred on the main London hospitals. As a teacher he was highly regarded and will be remembered for his interest in pharmacology. His lectures on 'Materia Medica' at the Royal Dental Hospital were the mainstay of pharmacology teaching

He qualified at RDH in 1938 and did house jobs both in Leicester Square and at the Middlesex (then the only resident dental post in the country and therefore much sought after). When the 'Phoney War' started in 1939 he found himself responsible for providing the only emergency service for central London. In 1941 he joined the RAF, where experience of maxillofacial injury was gained at home and abroad.

He became a medical student at the Middlesex Hospital after the war and did an ENT house job there in 1949. His first consultant post was at the Royal Marsden Hospital. The consultant post at the Royal Dental Hospital was gained in 1956 and included attendance at St

\section{Malcolm Joseph Munday}

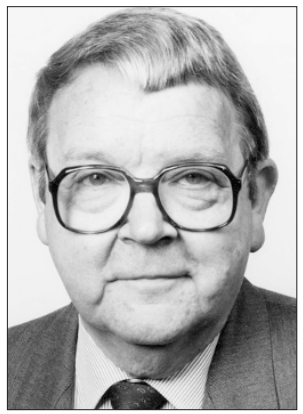

Malcolm Munday was born on 21st July 1926 in Adelaide, South Australia when Adelaide had been settled for 90 years .

Following his education at the local school, he went to Muirden College where he took a secretarial course. At the age of 15 he received the College's gold medal for being the fastest shorthand scholar in the College's history accomplishing 170 words a minute.

In 1944 during the war, when he was 18, he joined the 71st Squadron of the Royal Australian Air Force. He trained as a navigator but after one year peace was declared and he was discharged in September 1945.

In order to progress his education he went back to school to get matriculation qualifications so that he could take a University course in dentistry. He graduated as a Bachelor of Dental Surgery in December 1953.

The Dental Faculty in Adelaide was full of ex-servicemen who were accepted under a special government tertiary education scheme. During his undergraduate training he was taught orthodontics by Dr Raymond Begg. Malcolm was impressed with the way that Begg could move teeth and never forgot the training in the technique that he had received.

At that time there was little or no work for many newly graduated dentists in Australia so Malcolm and his family emigrated to England. The new NHS was crying out for dentists and he quickly found work as an assistant at a practice in Welwyn Garden City. Later he worked in Potters Bar and then set up a practice in Cheshunt.

After going to a meeting of the newly formed Begg Society in Chicago, he came home and proceeded to promulgate the Begg Technique in the UK where fixed appliances were seldom used. In the early sixties he wrote to orthodontists and invited them to form a UK Begg Study Group. The group met at University

\section{...he found himself responsible for providing the only emergency service for central London.}

George's Hospital at Tooting. Head and neck oncology preoccupied him at the Royal Marsden in the 1970s where it became a wellknown centre for referrals. He was subsequently called upon to give lectures abroad in Denmark, Holland, Spain, Portugal, north and south America and Asia.

He was a recognised teacher of the University of London, RDH, St Bartholomew's and the Institute of Cancer Research, London. Serving on various regional consultants' committees, he was also president of the Hospitals Group of the BDA in 1977 and was, for a time, Hon. Treasurer and Chairman of the Dentists' Provident Society.

His interests included athletics, sailing, skiing, cricket, furniture and clock restoration and travel. He was an enthusiastic gardener and spent much time at his cottage in West Wittering. He was a loyal and regular supporter of the Royal Dental OSSA Alumni lunches, held annually at Guy's Tower and in Leicester Square.

He is survived by his sister, Dorothy Elizabeth Williams.

D.C. Debuse

\section{He was held in high esteem by many and enjoyed his work very much indeed.}

College Hospital Dental School and provided a forum where orthodontists could meet and show their successes and failures to a small group of likeminded orthodontists. This continued for many years and Malcolm was the stimulus for the group.

He was also instrumental in forming the European Begg Society, and by sheer determination established a movement that has caused wide acceptance of fixed appliance therapy amongst the profession and patients in Europe.

As he became more and more involved in orthodontics he left the general practice in Cheshunt and joined the orthodontic practice of Grainger McCallum and Maurice Berman in Portland Place, and there he spent the rest of his professional life. The Royal Family recognised his expertise and he undertook orthodontic treatment for one of the princes.

He was elected President of the European Begg Society, the British Association of Orthodontists and the British Society for the Study of Orthodontics. He was also asked to join the Orthodontic Department at the Eastman Dental Hospital as a tutor.

He was held in high esteem by many and enjoyed his work very much indeed. Reluctantly he retired in 1994. Maureen and Malcolm were married on 1st December 1951 and celebrated their Golden Wedding Anniversary in December 2001.

Malcolm always worked very hard and was a perfectionist as seen in his excellent handiwork both in the mouth and at his home. He was a quiet, intelligent, shy, self-effacing man, always underestimating his own abilities, but proud of his achievements and his family. He was highly motivated, determined and persistent, and yet a humble and a private person. Many of us have been privileged and honoured to be associated with him, a true friend. Our thoughts and sympathy go to Maureen and the family at this time.

J. Moss 